\title{
"Kan man köra en skottkärra med fyrkantigt hjul?"' Läs- och skrivutvecklande praktiker $i$ teknikundervisning i förskoleklass
}

\author{
Tarja Alatalo* och Annie-Maj Johansson \\ Högskolan Dalarna
}

\begin{abstract}
Abstrakt
I den här studien är syftet att utveckla kunskap om läs- och skrivutvecklande sociala praktiker i teknikundervisning i en förskoleklass. Fyra tekniklektioner observerades med fokus på lärarens läs- och skrivutvecklande undervisning. Det teoretiska ramverket utgörs av Freebodys och Lukes resursmodell som beskriver läs- och skrivkunnighet som en uppsättning sociala praktiker. Dessutom analyseras huruvida läs- och skrivundervisningen är formaliserad, funktionaliserad eller om den är balanserad, det vill säga genomförs i sammanhang där formaliserad och funktionaliserad undervisning är i samspel med varandra. Resultatet visar att teknikundervisningen skapar rikliga möjligheter för elever att medverka i de sociala praktikerna i Freebodys och Lukes modell. Undervisningen är funktionaliserad och läraren undervisar inte explicit om språkets formaspekter eller om hur texters kommunikativa delar samspelar, utan det är oftast underförstått. Studien öppnar för en diskussion om förskoleklassens möjligheter att skapa läs- och skrivundervisning i balanserade sammanhang, för att stödja elevers läs- och skrivutveckling även när undervisningen har fokus på ämnesområden som teknik.
\end{abstract}

Nyckelord: Balanserad undervisning; läs- och skrivundervisning; sociala praktiker; sociokulturellt perspektiv; tekniklektioner

\begin{abstract}
"Can you drive a wheelbarrow with a square wheel?" Literacy practices in technology education in preschool class

The purpose in this study is to gain knowledge about literacy instruction by an expanded text concept during technology lessons in a preschool class. Four technology lessons were observed with focus on the teacher's literacy instruction. Freebody and Luke's four resources model, that describes literacy learning as a set of social practices, forms the theoretical starting point. Further, we analyze if the literacy instruction is accomplished by formal, functional or by integrated approaches, which means that the literacy instruction is embedded in a meaningful activity and studied in separate and structured contexts. We found that the technology lessons create rich opportunities for the students to participate in the social practices described in Freebody and Luke's model. The instruction has
\end{abstract}

^Korrespondens: Tarja Alatalo, Högskolan Dalarna, Akademin Utbildning, hälsa och samhäle, 791 88 Falun, Sverige. Epost: tao@du.se 


\section{T. Alatalo och A.-M. fohansson}

a functional approach, and the teacher does not teach about the formal aspects of the language or about how communicative parts in text interplay, thus it is mostly implied. The study opens for a discussion about the opportunities for the preschool class to create literacy instruction in integrated contexts to support the students' literacy development also when the teaching focus is on subject areas as technology.

Keywords: Integrated instruction; literacy instruction; four resources model; technology; social practices

Responsible editor: Victoria Johansson

Received: April, 2019; Accepted: November, 2019; Published: December, 2019

\section{Introduktion}

Tidig språkstimulans som ges i funktionella sammanhang och i en social kontext har visats vara av betydelse för barns läs- och skrivutveckling eftersom det ger barnet möjlighet att utveckla språket tillsammans med andra (Gillen \& Hall, 2003). Läroplanen (Skolverket, 2018) förespråkar en språkstimulerande undervisning i förskoleklass utifrån elevens behov, intressen och tidigare erfarenheter. Där framhålls att undervisningen ska ta tillvara elevernas nyfikenhet och ge dem möjlighet att utveckla sitt intresse för, och sin förmåga att kommunicera med, tal- och skriftspråk genom att skapa tillfällen för elever att läsa, lyssna på samt skriva och samtala om såväl skönlitteratur som andra typer av texter och händelser.

Barns tidiga skriftspråkslärande kan beskrivas som en utveckling där samtalandet, lyssnandet, skrivandet och läsandet går in i varandra i en social interaktion (se Björk \& Liberg 2003), vilket har varierade benämningar inom olika forskningsinriktningar. Barnets utforskande av språket i samspel med vuxna benämns emergent literacy och innebär att det växer fram en skriftspråklig kompetens (Clay, 1966). I en annan forskningsinriktning ses barnen i stället som litterata från början, och uppfattas agera med skriftspråket på sina egna villkor och på sätt som är meningsfulla för dem själva. Detta benämns early childhood literacy (Gillen \& Hall, 2003). Begreppet literacy innebär $i$ en svensk kontext att läsa och skriva i sociala sammanhang och inbegriper ett vidgat textbegrepp (Schmidt, 2016). Genom interaktion och kommunikation mellan deltagare, lika väl som mellan deltagare och text (som med vår textförståelse kan vara exempelvis skriven, muntlig, visuell i form av bild eller film), skapas mening och förståelse om omvärlden (Barton, 2007). Freebody och Luke (1999) talar om roller eller sociala praktiker som barn i den tidiga barndomens skolformer behöver medverka i för att utveckla läs- och skrivförmåga. De beskriver dem som praktiker som stödjer kodning, meningsskapande utifrån text, textanvändning samt praktiker som skapar utrymme för kritisk analys. I den här studien betraktas därför de läs- och skrivutvecklande aktiviteter som skapas i undervisning som en repertoar av sociala praktiker (Freebody \& Luke, 1999; Jönsson \& Bergöö, 2012), som med ett vidgat textbegrepp kan benämnas texthändelser. 
Elevers förmåga att förstå innebörden i en text utvecklas av kontinuerliga samtal om textens innehåll och budskap samt genom att lärare och elever gemensamt tränar på strategier för att förstå text (Beck \& McKeown, 2007). Sådana samtal kännetecknas av en dialog utifrån elevers intresse och nyfikenhet som knyter an till deras erfarenheter och associerar till andra texthändelser samt har ett kritiskt förhållningssätt till den aktuella textens innehåll och form (Palincsar \& Brown, 1984). Detta kan också beskrivas som textrörlighet, att röra sig inom texten på en ytlig och/eller djup nivå, att röra sig utåt genom att knyta textinnehåll till egen erfarenhet eller andra texter och interaktiv rörlighet som innebär att sätta texten i relation till dess syfte, sammanhang, tänkta mottagare etc. (Wiksten Folkeryd, af Geijerstam \& Edling, 2006).

Ordförråd har visats korrelera starkt med läsförståelse (Pearson, Hiebert \& Kamil, 2007), och kan utvecklas genom implicit undervisning i social interaktion, det vill säga genom att eleverna möter nya ord exempelvis under högläsning och i samtal om det lästa (Hindman, Wasik \& Erhart, 2012). Läraren behöver vidare undervisa om hur sammansatta ord är uppbyggda av grundord, både för att stödja eleverna att härleda ordsammansättningarna till grundorden för att förstå det sammansatta ordet, och för att veta hur de stavas var för sig, vilket är av betydelse när man ska stava ordsammansättningar (Nauclér, 1989). Explicit undervisning om innebörden av ord i samband med undervisning i meningsfulla sammanhang i olika ämnen är ett annat gynnsamt sätt att undervisa om ords betydelse (Wright \& Neuman, 2013). Forskning har visat att det är mest fördelaktigt för elevernas ordförrådsutveckling att kombinera implicit och explicit undervisning om ords innebörd (Wright \& Neuman, 2015).

En rad studier (t.ex. Dickinson \& Caswell, 2007; Lonigan, 2015) har dessutom visat att lärare som engagerar eleverna i rik språklig interaktion hjälper dem att bli känsliga för ljud och bokstäver i ord genom att exempelvis undervisa om bokstäver i samband med högläsning, vilket främjar läsinlärningen (Lonigan, 2015).

Förskoleklassens skriftspråkstimulerande undervisning är betydelsefull eftersom det under senare årtionden har blivit tydligt att läs- och skrivutvecklingen i tidiga skolår korrelerar positivt med senare skolgång (t.ex. Cunningham \& Stanovich, 1997; Schatschneider, Fletcher, Francis, Carlson \& Foorman, 2004). Forskningslitteratur förespråkar en kombination av den kognitiva forskningens kunskapsbidrag om skriftspråksförberedande förmågor och den sociokulturella forskningens kunskaper om meningsskapande texthändelser för att ge eleverna gynnsamma förutsättningar att utveckla läs- och skrivkunnighet för att kunna bli aktiva i ett demokratiskt samhälle (Langer, 2001; Liberg, 2008; Freebody \& Luke, 1999). Freebodys och Lukes (1999) modell för läs- och skrivundervisning, som kombinerar dessa forskningsperspektiv, utgör det teoretiska ramverket för den här studien. Vi kommer också att analysera den läs- och skrivutvecklande undervisningen utifrån begreppen formaliserad, funktionaliserad och balanserad undervisning (Langer, 2001; Liberg, 2008) för att förstå och beskriva hur lärarens undervisning är konstruerad. I en formaliserad undervisning sker undervisningen av det som ska läras isolerat från ett sammanhang. I en funktionaliserad undervisning sätts det som ska läras in i ett 
sammanhang där det fyller en funktion, men utan att det undervisas närmare om det språkliga. I en balanserad undervisning integreras det som ska läras i en helhet och ett sammanhang där det fyller en funktion, och studeras också separat i väl strukturerade sammanhang.

Svensk forskning som studerat förskoleklassens praktik, har funnit att läs- och skrivundervisningen i förskoleklassen huvudsakligen sker i formaliserade sammanhang och utan koppling till elevers erfarenheter (Aminoff, 2017; Fast, 2007; Sandberg, 2012; Skoog, 2012). Forskarna framhåller betydelsen av att skriftspråklig verksamhet genomförs i språkutvecklande sammanhang och utifrån elevernas intresse, vilket är ett centralt fokus i den här studien. Den tidigare forskningen har främst analyserat samtals- och skriftspråksorienterade lärarledda aktiviteter, medan vi fokuserar läs- och skrivutvecklande praktiker inom ämnesområdet teknik. Skolverket (2012) lyfter fram behovet av språkutvecklande undervisning i alla ämnen i skolan eftersom språket är grunden för lärandet och för elevers möjlighet att nå de kunskapskrav som kursplanerna ställer.Ytterligare ett argument för att skapa språkutvecklande undervisning i förskoleklassens olika ämnesområden är att man har funnit att sexårsåldern är en tid då det sker rikligt med skriftspråklig utveckling hos eleverna (Hofslundsengen, Eriksen Hagtvet \& Gustafsson, 2016). Det är dessutom visat att en språkstimulerande undervisning gynnar alla elever, men särskilt dem från mindre fördelaktiga omständigheter och som kanske inte har en språkstimulerande hemmiljö (Cummins, 2011; Lonigan, 2015).

Syftet i den här studien är att utveckla kunskap om läs- och skrivutvecklande praktiker i teknikundervisning i en förskoleklass. Följande forskningsfråga är central:Vilken läs- och skrivutvecklande undervisning möjliggörs i teknikundervisningen? Vi avser att synliggöra vilka möjligheter till meningsskapande texthändelser, som vi ser som läs- och skrivundervisning, som finns i teknikundervisningen. Här studeras således endast vilka möjligheter undervisningen ger till elever att medverka i praktiker som stöder läs- och skrivutveckling, inte vad eleverna lär sig.

\section{Läs- och skrivutvecklande undervisning}

Förskoleklassens läs- och skrivutvecklande undervisning har studerats i flera svenska avhandlings- och licentiatstudier genom i huvudsak observation av klassrumspraktiker. I Sandbergs (2012) studie beskrev någon av lärarna hur eleverna hade inslag av skriftspråket i sin "fria" lek, men i övrigt skedde det lekbaserade skriftspråkslärandet genom att eleverna spelade spel eller lade pussel med till exempel bokstäver som inslag. Fast (2007) såg att elever praktiserade skriftspråket i en rad texthändelser i samband med populärkultur och medier, men att alla lärare inte uppfattade det som betydelsefullt. Hon konstaterar att inlärningen endast i liten grad kopplades till elevernas vardag och erfarenheter, något som även andra studier påvisat (Aminoff, 2017; Lago, 2014; Skoog, 2012). Aminoff (2017) fann att alla elever i de studerade förskoleklasserna oftast gjorde samma skriftspråkliga uppgifter, och att en utvecklad 
individanpassning av undervisningen saknades. Fast (2007) och Skoog (2012) konstaterar att elevernas erfarenheter av läsande och skrivande innan de kommer till förskoleklassen inte tas tillvara i undervisningen, och ser en risk att de textvärldar som eleverna möter i skolan inte är desamma som på fritiden. Fast (2007), Skoog (2012) och Aminoff (2017) fastslår att undervisningen i hög grad liknar skolans traditionella undervisning, där elevernas skrivande i huvudsak är ett återgivande skrivande, vilket innebär att återge ord som andra valt till skillnad från att välja orden själva. Exempel på sådan undervisning är att skriva $i$ arbetsböcker, att skriva av en text som läraren skrivit och att träna bokstävernas form.

Skoog (2012) observerade lärarledda textorienterade aktiviteter i två förskoleklasser och två grupper i årskurs ett med avseende på hur det tidiga skriftspråkslärandet konstrueras. Hon fann att eleverna framför allt fick träna olika kodningsfärdigheter (jfr Freebody \& Luke, 1999), samt att läsandet och skrivandet var dekontextualiserat och genomfördes i formaliserade sammanhang. Dialogerna i Skoogs studie var tvåstämmiga så tillvida att de i huvudsak skedde mellan läraren och en elev i taget. Läraren kontrollerade turtagningen och initierade de samtalsämnen som togs upp till diskussion, vilket minskade elevernas möjligheter att utveckla längre tankekedjor och fördjupade resonemang kring de ämnen som togs upp. Skoog såg vidare att läraren ställde frågor i samband med högläsning av till exempel faktatext, men att det inte förekom textrörlighet i form av att samtalet rörde sig ut ur texten eller kopplade till elevernas egna erfarenheter. Det saknades också exempel på kritiskt utforskande av olika texter i det som lästes. Skoog konstaterar att ett kognitivt synsätt på läs- och skrivutveckling var förhärskande i högre grad än synen på läs- och skrivhändelser som meningsskapande i social interaktion.

\section{Teoretiska utgångspunkter}

Studiens teoretiska ramverk utgörs av Freebodys och Lukes (1999) resursmodell "Four sources model", som beskriver läs- och skrivkunnighet som en uppsättning sociala praktiker, som kan uppfattas som resurser som elever behöver få tillgång till för att utveckla läs- och skrivförmåga. Freebody och Luke betonar att elevers läs- och skrivutveckling ska förstås utifrån samhälleliga, kulturella och sociala förhållanden. Eftersom den föreliggande studiens fokus är läs- och skrivutvecklande praktiker i form av textutforskning och meningsskapande i teknik, använder vi Freebodys och Lukes resursmodell till att analysera, förstå och synliggöra vilka läs- och skrivutvecklande möjligheter undervisningen erbjuder eleverna. Kognitiv och sociokulturell teori samspelar i modellen genom att elevernas individuella kognitiva förmågor påverkar inlärningen, medan den sociala praktiken är av en central betydelse för lärandet. I vår läsning av Freebodys och Lukes modell handlar det om att i exempelvis förskoleklass erbjuda möjligheter för alla elever att utifrån sina egna förutsättningar medverka i en repertoar av sociala sammanhang där de ges möjlighet att såväl muntligt, skriftligt som visuellt både skapa text och utveckla förståelse för texter som finns i 
samhället. I begreppet praktiker ligger dynamik, förändring, nya kombinationer och att olika praktiker relateras till varandra som resurser för att lära, förstå, skapa och använda olika slags text. Genom att uppmärksamma läs- och skrivkunnighet som sociala praktiker och resurser för lärandet hamnar inte fokus på undervisningsmetoder eller material (Comber, 1997). Som tidigare beskrivits, fokuserar de fyra praktikerna i resursmodellen följande verksamhet i sociala sammanhang: att koda text, skapa mening av text, använda text funktionellt och att kritiskt analysera och transformera text. De fyra praktikerna förklaras närmare nedan. Freebody och Luke (1999) poängterar att praktikerna går i varandra och att var och en är nödvändig men inte $i$ sig tillräcklig för att utveckla läs- och skrivkompetens. I den här studien analyserar vi hur läraren i sin undervisning muntligt skapar praktiker där eleverna ges möjlighet att tillsammans medverka och skapa mening om och utifrån text med utgångspunkt i sina tidigare erfarenheter.

Resursmodellens första praktiker stödjer kodning, och är en resurs där eleverna ges möjlighet att förstå och utveckla samband mellan bokstäver och ljud i såväl läsning som skriven text samt lära sig att känna igen strukturer och mönster, stavning och skriftspråkskonventioner (Freebody \& Luke 1999; Luke, 2000). I vår läsning av Freebody och Luke handlar det om att erbjuda möjligheter för alla elever oavsett bakgrund att medverka i kodningspraktiken i exempelvis leksammanhang, men också genom att läraren i meningsfulla sammanhang visar hur bokstäver, ord och meningar skrivs och läses, samt stödjer eleverna att själva ljuda ihop bokstavsljud och att skriva. Vi menar att undervisning i ordkunskap kan innefattas i en kodningspraktik genom att ord byggs upp av betydelsebärande och betydelseskiljande strukturer, vilket $\mathrm{i}$ praktiken kan vara exempelvis ordsammansättningar.

De andra praktikerna i resursmodellen stödjer textskapande, vilket innebär att elever genom att medverka i och skapa olika typer av meningsfulla texter, såväl visuella, skrivna som muntliga, kan förstå och skapa mening utifrån sina egna erfarenheter (Freebody \& Luke, 1999; Luke, 2000). Det kan vara att fokusera på förståelse av textens innebörd och olika texttypers syfte, struktur och ton. I praktiker som stödjer textskapande ges elever möjlighet att utveckla resurser genom att skapa mening i olika texters meningssystem och använda olika slags texter i olika sammanhang. Därigenom får eleverna vara medvetna textskapare (Freebody \& Luke, 1999, se också Bergöö \& Jönsson, 2012).

De tredje praktikerna i resursmodellen stödjer textanvändning, och innebär att använda texter på ett funktionellt sätt och förstå hur olika texter används och fungerar i disparata sammanhang (Freebody \& Luke, 1999; Luke, 2000). Genom att få ta del av texter från olika sociala och kulturella kontexter, i och utanför skolan, utvecklas förståelse för att texters funktion, det vill säga syftet med texten, är grundläggande för hur olika texttyper konstrueras och struktureras, vilken ton de har och hur formella de är (Bergöö \& Jönsson, 2012; Freebody \& Luke, 1999).

De fjärde och sista praktikerna i resursmodellen skapar utrymme för kritisk analys. Här ges eleverna möjlighet att kritiskt analysera och transformera text utifrån 
kunskaper om att texter inte är neutrala utan att de alltid representerar något perspektiv samtidigt som de utesluter andra (Freebody \& Luke, 1999; Luke, 2000). Fokus för denna praktik är att förstå hur texter konstrueras för olika sammanhang. Här ansluter vi oss till Bergöö och Jönsson (2012), som diskuterar kritisk analys av text utifrån att texter skapar olika bilder av världen genom ordval och uttryckssätt, vilket också inkluderar elevers egna berättelser och utvidgande av hur text kan förstås. För att hjälpa elever att bli kritiska till text behöver de få samtala om och undersöka andras texter och även förändra, gestalta och skriva om skrivna eller muntliga texter i ett socialt sammanhang (Bergöö \& Jönsson, 2012; Freebody \& Luke, 1999).

Liberg (2008) och Langer (2001) diskuterar tre skilda sätt att skapa skriftspråksundervisning, vilket är ett teoretiskt verktyg för oss i analyser av genomförandet av den läs- och skrivutvecklande undervisning som synliggörs med Freebodys och Lukes (1999) resursmodell. Ett sätt är att undervisa om exempelvis ordkunskap separerat och utan att sätta in det $\mathrm{i}$ ett sammanhang, så kallad starkt formaliserad undervisning. En annan undervisningsform är att sätta in det som ska läras, exempelvis ordkunskap, i ett sammanhang där det fyller en funktion, men utan att uppmärksamma eleverna explicit på exempelvis hur två ord satts ihop, utan det lämnas till dem att själva upptäcka. Liberg kallar detta starkt funktionaliserad undervisning. En tredje väg att gå är att integrera exempelvis en formaliserad ordkunskapsundervisning i en helhet och ett sammanhang där det fyller en funktion, men att också studera det som ska läras separat i väl strukturerade sammanhang. Liberg (2008, s. 61) förespråkar det tredje sättet, som hon kallar balanserade undervisningssammanhang, där språkets funktion, form och innehåll, som här även uppfattas som textens syfte, struktur och ton, är i samspel med varandra. I en sådan undervisning förväntas eleverna använda sina förmågor och sitt kunnande i meningsfulla sammanhang. Exempelvis kan läraren påminna om stavningsregler som eleverna tidigare lärt sig i formaliserade eller funktionaliserade sammanhang (Langer, 2001). Langer visar i en tvåårig studie av 44 lärares undervisning att de mest framgångsrika lärarna integrerade formaliserad undervisning i en kontext som var meningsfull för eleverna. Genom att analysera hur formell eller funktionaliserad undervisningen är kan vi förstå och beskriva lärarens undervisning på ett djupare plan.

\section{Metod}

Studien har genomförts som en fallstudie. Med fallstudie avses en empirisk studie som studerar en aktuell företeelse i dess verkliga kontext (Yin, 2015). I denna studie är den aktuella företeelsen de läs- och skrivutvecklande erfarenheter som lärare möjliggör i teknikundervisning där lärare och elever talar om teknikens uppkomst och funktion, medan kontexten är lärarens planerade tekniklektioner i förskoleklass. Studien har genomförts som en observationsstudie i en förskoleklass. Endast lärarens handlingar är aktuella för observation, varför elevernas röster inte är synliga. 


\section{Studiens sammanhang och genomförande}

Observationerna genomfördes under våren 2017. I klassen undervisade en förskollärare och en lärare. Båda lärarna undervisade vid samtliga observationstillfällen. Förskoleklassen bestod av 15 elever som var sex eller sju år. Teknikundervisningen genomfördes vid sex tillfällen varav fyra lektioner har observerats. Vid de två första observationstillfällena diskuterade lärare och elever vad som är och inte är teknik, samt teknikens uppkomst och funktion. Vid dessa tillfällen satt elever och lärare i en ring på golvet, lärarna fördelade ordet och uppmuntrade eleverna att berätta om sina erfarenheter. Vid det tredje observationstillfället var syftet med undervisningen att bygga och konstruera en koja samt att laga mat i en kokgrop. För att nå syftet bedrevs undervisningen utomhus i en närbelägen skog. Vid det fjärde observationstillfället var syftet att reflektera över och dokumentera vad gruppen giort under de tidigare tekniklektionerna. Eleverna satt vid det lektionstillfället vid sina bänkar och dokumentationen genomfördes delvis gemensamt på ett stort papper och delvis enskilt $\mathrm{i}$ elevernas skrivhäften.

Datainsamlingen genomfördes med hjälp av kvalitativa, icke-deltagarorienterade, observationer för att få syn på lärarnas handlingar i undervisningen (Hammersley \& Atkinson, 2007). Båda författarna (hädanefter forskare a och b) observerade undervisningen och satt längst bak i klassrummet samt höll sig vid sidan av verksamheten vid observationerna utomhus. Observationstillfällenas längd varierade från ca två timmar till ca fem timmar. Observationerna dokumenterades av båda forskarna med hjälp av fältanteckningar och ljudinspelning av lärarna. Sammanlagt genomfördes 660 minuter observation, se Tabell 1.

Tabell 1. Undervisningens innehåll och antal minuter observation.

\begin{tabular}{ll}
\hline Undervisningsinnehåll & Observation (minuter) \\
\hline Vad är och vad är inte teknik? & 120 \\
Teknikens uppkomst och funktion & 120 \\
Bygga och konstruera en koja, laga mat i en kokgrop & 300 \\
Reflektion över och dokumentation av vad de gjort under tidigare lektioner & 120 \\
\hline
\end{tabular}

\section{Urval av informanter}

Urvalet av skola är bekvämlighetsurval, vilket innebär att forskaren söker informanter som finns nära tillhands (Patton, 1990), i vårt fall inom ett rimligt pendelavstånd. Lärarna i studien har valts utifrån premisserna att de undervisar i förskoleklass och inom ämnesområdena natur och/eller teknik. Förskolläraren har undervisat i ca 30 år, varav ca 15 år i förskoleklass, och läraren har undervisat i mindre än 10 år, varav 1 år i förskoleklass. Vi har valt att inte särskilja förskollärarens och lärarens insatser i undervisningen, utan de anges som "läraren" i resultat och analyser för att avidentifieras (Hammersley \& Atkinson, 2007). 


\section{Databearbetning och analys}

Insamlade data, det vill säga den ena forskarens (forskare a:s) fältanteckningar samt inspelat material har transkriberats och sammanställts kronologiskt genom att transkriptioner och fältanteckningar från samma tillfällen har placerats bredvid varandra. Materialet har därefter lästs igenom ett flertal gånger av båda forskarna för att få en överskådlig förståelse för innehållet. Därefter har materialet analyserats och kategoriserats med hjälp av Freebodys och Lukes (1999) fyra praktiker som fokuserar på kodning, textskapande, textanvändning och kritiskt utforskande. Kategorierna framträdde i materialet genom att likheter och olikheter samt mönster undersöktes och kodades. Kodningen har först genomförts av forskare a och därefter av forskare b. Det har varit nödvändigt att diskutera kodningen eftersom de fyra praktikerna beskriver dynamik och förändring i social interaktion och därför kan uppfattas som överlappande. Efter att ha diskuterat och undersökt material och kodning i omgångar har forskarna enats om kodning och kategorisering av materialet. I resultatavsnittet sammanfattas och ges exempel på undervisning som kategoriserats i olika praktiker. Eftersom studien är avgränsad till planerade tekniklektioner, har endast undervisningen som läraren uppgivit som teknikundervisning observerats. Exempel på kategoriseringar framgår i Tabell 2.

Tabell 2. Exempel på kategorisering av observerat material utifrån Freebodys och Lukes (1999) fyra praktiker. Inom citattecken återges citat från läraren.

\begin{tabular}{ll}
\hline Exempel från observationer & Praktiker \\
\hline "När man gör så här då heter det att man siktar och det & Kodning \\
är inte samma sak som när man siktar när man skjuter & Språkets form och innehåll uppmärksammades \\
heller.” & genom fokus på att samma ord kan ha olika \\
& betydelse.
\end{tabular}

Eleverna gavs talutrymme för att skapa egna muntliga beskrivningar av olika tekniska köksredskap.

Eleverna erbjöds att berätta om hur de brukar göra när de ska göra upp eld. "Hur gör ni när ni ska göra upp eld?"

\footnotetext{
"Idag när vi jobbar med det här så bläddrar man framåt så här och till slut kommer man till en tom sida och då vill man ju ha en liten rubrik om det vi gjorde i går, man får bestämma själv vad man vill berätta, då skriver ni vad ni gjorde och så kan man rita en bild till.”
}

\section{Textskapande}

Eleverna erbjuds att meningsskapa och utforska text i social interaktion.

\section{Textanvändning}

Genom att läraren gav eleverna muntliga instruktioner erbjuds eleverna förstå syftet och strukturen av beskrivande text.

\section{Kritiskt utforskande}

Eleverna erbjuds att ta del av att texter inte är neutrala utan att de representerar ett visst sätt att se på världen. 
I ett andra steg har materialet analyserats av en av forskarna (forskare b) med avseende på hur den läs- och skrivutvecklande undervisningen genomförs, om den kan sägas vara formaliserad, funktionaliserad eller balanserad utifrån Libergs (2008) och Langers (2001) definitioner. För att stärka analysen har båda forskarna om igen läst materialet och studerat analysen varpå vi diskuterat den utifrån vår förståelse av Libergs och Langers begrepp.

Författarna av föreliggande studie har själva lärarerfarenhet, vilket kan ses såväl som en styrka som en svaghet i forskningsprocessen (Patton, 1990). Å ena sidan har det varit en styrka i observationer av lärarens handlingar i undervisningen samt $i$ förståelse och tolkning av transkriptioner av observerad undervisning. Å andra sidan har det varit nödvändigt att sträva efter att distansera sig och att förhålla sig neutral i tolkningar och analyser för att motverka risken att otillbörligt påverka resultatet. Detta har vi kontinuerligt återkommit till under forskningsprocessen.

\section{Forskningsetiska hänsynstaganden}

Vetenskapsrådets (2017) forskningsetiska rekommendationer om information och samtycke, rätt att avbryta medverkan samt avidentifiering och konfidentialitet har fölits. Informerat samtycke har inhämtats från de medverkande lärarna. Vidare har lärare, föräldrar och elever informerats om att observationer av undervisning genomförs samt att inga namn på personer eller på skolan kommer att anges vid publikation. Inför de första observationerna informerades eleverna om varför vi fanns i deras klassrum, vilket de verkade vara tillfreds med. Alla personuppgifter har behandlats enligt Dataskyddsförordningen (GDPR, 2016).

\section{Resultat}

Här presenteras resultatet avseende de fyra olika praktikerna i tur och ordning: kodning, textskapande, textanvändning och kritisk analys. I analyserna av materialet framkom texthändelser $i$ alla fyra praktikerna, men den textskapande praktiken var mest framträdande och ges därför mer utrymme i resultatet än de tre övriga. Inom varje praktik synliggörs tillfällen $i$ teknikundervisningen när läraren skapar möjligheter för elever att medverka i läs- och skrivutvecklande texthändelser. De situationer som beskrivs är exempel som vi uppfattar som typiska för respektive praktik. Resultatpresentationen inom vardera praktiken följs av en analys utifrån Langers (2001) och Libergs (2008) beskrivningar av tre olika sätt att skapa läs- och skrivundervisning.

\section{Praktiker som stödjer kodning}

Vid några tillfällen under teknikundervisningen gavs eleverna möjlighet att meningsskapa om teknik i praktiker som stödjer kodning såväl enskilt som tillsammans med andra. Meningsskapandet innebar bland annat att elever och lärare samtalade om specifika teknikinriktade ords form och innebörd samt att de, med lärarens stöd, 
läste skriven text och bilder samt skrev ord och meningar. Olika innebörder av ordet "sikta" uppmärksammades till exempel när läraren berättade att hen använder tesilen för att "sikta" florsocker på kakor. Eftersom läraren uppmärksammades av elever på att ordet sikta även kan innebära att sikta på något, förklarade hen betydelsen för eleverna: "När man gör så här då heter det att man siktar och det är inte samma sak som när man siktar när man skjuter heller."

Läraren var oftast den som tog initiativet till att förklara innebörden av ord eller begrepp. Ord som exempelvis "näver" och "braständare" förklarades i samband med att lärare och elever gjorde upp eld. Läraren uppmärksammade däremot inte eleverna explicit på vilka ord exempelvis "braständare" var sammansatt av. Vid andra tillfällen framkom att tekniska föremål, som exempelvis konservöppnare, kan se olika ut men benämns med samma ord. Ord uppmärksammades också genom att läraren lekte med ord genom att rimma, sjunga eller sätta ihop olika ord på nya sätt. Läraren sjöng exempelvis: "Lite blåbär, lite blåbärslax, lite tallbarrslax" och visualiserade ordsammansättningarna genom att samtidigt krydda fisken med blåbärsris och tallbarr. Eleverna gavs vid det här tillfället möjlighet att meningsskapa om innebörden av ord i ett funktionellt sammanhang. Läraren förklarade däremot inte explicit vilka ord som satts ihop, eller hur de satts ihop, utan det lämnades till eleverna att upptäcka själva.

\section{Analys av undervisningens genomförande}

Vi ser att teknikundervisningen möjliggjorde många tillfällen för eleverna att meningsskapa i kodningspraktiken genom att läraren exempelvis lyfte fram och visualiserade ord och begrepp som "blåbär", "blåbärslax" och "tallbarrslax" i funktionella sammanhang. Vår analys är att läs- och skrivundervisningen genomfördes i en starkt funktionaliserad praktik, det vill säga i ett sammanhang som fyller en funktion men där eleverna inte är uppmärksammade på, i det här fallet, vilka ord som var sammansatta eller vad det innebär. För att nyttja det meningsfulla sammanhanget i teknikutforskandet till att rikta undervisningen mot elevernas läs- och skrivutveckling, hade läraren kunnat uppmärksamma eleverna explicit även på språkets formaspekter. Exempelvis när orden blåbär och tallbarr kom på tal, hade läraren kunnat konkret åskådliggöra att blåbär är blåfärgade bär och att tallbarr är barr på en tallkvist, vilket hade kunnat utvecklas till en balanserad läs- och skrivundervisning (jfr Langer, 2001; Liberg, 2008).

\section{Praktiker som stödjer textskapande}

Eleverna gavs möjlighet att meningsskapa om teknik i flera olika praktiker som stödjer textskapande i olika texttyper, som exempelvis beskrivande, sammanfattande och instruerande. Texterna uttrycktes i form av samtal, bilder, filmer och skriven text. Nedan ges några exempel på sådan undervisning.

Den allra första tekniklektionen inleddes med att läraren erbjöd eleverna att utifrån sina erfarenheter berätta vad de anser att teknik kan vara: "Är det någon som har pratat 


\section{T. Alatalo och A.-M. fohansson}

hemma om vad teknik kan vara? Få höra hur ni tänker?" Det framkom att olika fordon och teknik-Lego kunde vara teknik. Läraren accepterade förslagen: "Ja just det" och erbjöd eleverna att berätta mer om vilka fordon de hade hemma. I det här sammanhanget rörde sig samtalet ut och in ur texten, det vill säga vad teknik är och vilka leksaksfordon eleverna har hemma. Därefter visade läraren en bild på en flicka från stenåldern som använder en pinne för att göra små hål $i$ jorden för att kunna så frön. Läraren förde åter samtalet ut ur texten genom att hänvisa till när klassen sådde solrosfrön och hur de gjorde hål i jorden: "Kommer ni ihåg att ni gjorde hål i jorden när ni stoppade ner era solrosfrön, då var det ju litet men nu skulle flickan på bilden plantera så mycket (...) då var det en smart teknik att hitta på att använda en pinne.” Därefter fortsatte samtalet med att läraren beskrev hur teknik har förändrats genom åren:

Sen tänkte de lite mer, först började det så här att flickan tänkte att det var enklare att använda en pinne än att krafsa med fingrarna, sen kom de på ännu mera teknik när de skulle så på åkrarna och då kom de på att de kunde använda en ko.

Det gemensamma skapandet av en muntligt beskrivande text avslutades med att läraren sammanfattade vad de kommit fram till: "Teknik är något man kan få hjälp av och allt som vi har kommit på, jättebra!”

Vid det andra observationstillfället gavs eleverna talutrymme för att skapa egna muntliga beskrivningar av olika tekniska köksredskap. Läraren skapade sådana förutsättningar genom att varje elev fick välja ett köksredskap, exempelvis potatispress, vitlökspress och tesil, som även fanns fysiskt framför eleven när hen berättade om redskapet. Elever och lärare hade också repeterat vad teknik var och på så sätt skapat ett syfte och ett sammanhang som eleverna kunde utgå från när de berättade om det valda köksredskapet. När eleverna berättade, stöttade läraren dem genom att ställa frågor om varför det valda redskapet räknades som teknik. Genom elevernas berättelser och lärarens stödjande frågor förändrades och vidgades beskrivningen av begreppet teknik ytterligare. Innehållet i de gemensamma muntligt beskrivande texterna formades dels genom att elevernas erfarenheter hela tiden var utgångspunkten i meningsskapandet, dels genom att läraren förändrade sammanhanget i texterna så att eleverna fick berätta om andra erfarenheter som de kunde relatera till i det nya sammanhanget. Inga språkliga aspekter lyftes av läraren.

I början och i slutet av tekniktemat sammanfattade och punktade läraren upp elevernas förslag på vad teknik kunde vara, för att eleverna skulle kunna jämföra sina uppfattningar före och efter temat. Genom att läraren skrev punktlistor gavs eleverna möjlighet att medverka i textskapande av punktlistor som hade funktionen att sammanfatta och hjälpa dem att minnas från ett tillfälle till ett annat. Läraren uttryckte att genom att jämföra dessa två punktlistor så erbjöds eleverna att få insikt i vad de har lärt sig under tekniktemat. Eftersom den skriftliga dokumentationen var en sammanfattning och skriven i punktform erbjöds eleverna också att se vad i deras gemensamma samtal som var väsentligt utifrån undervisningens syfte. Samspelet mellan textens form, funktion och innehåll blev därmed relativt synligt, även om läraren inte undervisade explicit om det. 
Vid ett tillfälle erbjöds eleverna att skapa en muntlig instruktionstext genom att läraren bad dem berätta och förklara hur man kan göra upp eld. Lärare och elever var vid det tillfället ute i en skolskog och skulle laga mat i en kokgrop. För att värma stenar till kokgropen behövde de en eld och när lärare och elever var samlade runt eldstaden, erbjöds eleverna att berätta om hur de brukar göra när de ska göra upp eld. Det framkom att eleverna brukar använda ved och bygga eldstaden som ett Kapla-torn. Läraren bekräftade eleverna och byggde efter deras förslag: "Jaha ni bygger som ett Kapla-torn". Läraren stöttade eleverna samtidigt med frågor: "Bygger ni så här?" Därefter diskuterade de hur högt Kapla-tornet ska vara och vad eleverna brukar placera i mitten på Kapla-tornet. "Och i mitten på det vad lägger ni där?” På det viset skapades instruktionstexten i social interaktion och utifrån elevernas erfarenhet. Vid det här tillfället var det läraren som följde elevernas beskrivningar och instruktioner. Textens funktion var tydlig, det vill säga att eleverna skulle beskriva hur man gör upp eld. Genom att läraren ställde frågor när hen inte förstod, fick eleverna återkoppling på vilket innehåll som behövs i en instruktionstext om att göra upp eld. Eleverna gavs på det viset möjlighet att utveckla sitt sätt att förklara hur de brukar göra, vilket innebar att de skapade en instruktionstext. Däremot skedde ingen uttrycklig undervisning om hur form, funktion och innehåll samspelar, utan det var underförstått. Inte heller nämndes det explicit vilka texttyper som behandlades i undervisningen.

Eleverna gavs också möjlighet att sammanfatta innehållet i den föregående dagens teknikundervisning genom att skriva och rita. Vid dessa tillfällen repeterade läraren först vad klassen hade gjort under förra lektionen för att därefter instruera om vad de skulle göra nu.

Här har vi skrivboken och då ska vi jobba vidare med teknik, [...] idag när vi jobbar med det här så bläddrar man framåt så här och till slut kommer man till en tom sida och då vill man ju ha en liten rubrik om det vi gjorde i går, man får bestämma själv vad man vill berätta, då skriver ni vad ni gjorde och så kan man rita en bild till.

Läraren uttryckte inte tydligt syftet med skrivandet eller att det var en sammanfattning av gårdagens undervisning.

\section{Analys av undervisningens genomförande}

Teknikundervisningen möjliggjorde för eleverna att meningsskapa i många olika texthändelser. Vår analys är att läs- och skrivundervisningen i de textskapande praktikerna var starkt funktionaliserad. Lärare och elever utforskade teknikhändelser genom att skapa beskrivande och instruerande texter, där form och innehåll samarbetade med textens funktion, och där eleverna var medskapare av texten. Genom att i teknikutforskandets funktionella och meningsfulla sammanhang också stanna upp och synliggöra och jämföra på vilket sätt form, funktion och innehåll i olika texttyper samverkar, hade läraren kunnat utveckla läs- och skrivundervisningen så att formalisering och funktionalisering var i balans (jfr Langer, 2001; Liberg, 2008). 


\section{T. Alatalo och A.-M. Fohansson}

\section{Praktiker som stödjer textanvändning}

Under tekniklektionerna erbjöds eleverna att meningsskapa om teknik i muntliga, skrivna och visuella praktiker som stödjer användningen av en rad olika texttyper: sammanfattande, berättande, beskrivande och instruerande texter samt innehållsförteckningar. Nedan ges exempel på användandet av beskrivande faktatext i form av bilder.

Eleverna erbjöds att utforska teknikhändelser utifrån bilder, och innehållet i bilderna skapade vid flera tillfällen underlag för elevers och lärares samtal. Eleverna blev exempelvis ombedda att beskriva vilka tekniska föremål de såg på bilden eller vilka föremål som inte var tekniska. Exempel på sådana bilder är flickan med pinnen som nämnts tidigare samt en bild på ett kök och ett sovrum. Bilderna uppmärksammades för att de innehåller information om vad som är teknik. Vår tolkning är att bilder användes för att möjliggöra för elever att tillsammans läsa och utforska teknikrelaterad information i visuell text som ett komplement till skriven text. När eleverna erbjöds att läsa skrivna texter, var det främst läraren som tolkade och förklarade texternas innehåll.

Vid ett tillfälle gavs eleverna möjlighet att läsa en bild med två seriefigurer. Seriefigurerna hade var sin skottkärra, varav den ena hade ett runt hjul och den andra ett fyrkantigt hjul. Läraren förklarade för eleverna vad bilden föreställde och vad seriefigurerna sa. Därefter lät läraren eleverna tolka och förklara poängen i bilden. Läraren ställde en fråga som eleverna fick fundera på: "Han har ett fyrkantigt hjul, hur tror ni det skulle vara att köra en skottkärra med ett fyrkantigt hjul? Skulle det gå lätt eller tungt eller?” Eleverna erbjöds på det viset möjlighet att meningsskapa om teknik med hjälp av bilden, tillsammans och med hjälp av lärarens frågor. Det språkliga, exempelvis varför det heter fyrkantigt hjul, eller hur ordet sammansatts, togs inte upp trots att det fanns möjligheter till ett utforskande även om språket utifrån bilden. Inte heller lyftes det på vilket vis en bild också kan vara en faktatext.

\section{Analys av undervisningens genomförande}

Teknikundervisningen gav rikligt med möjligheter för eleverna att gå ut och in i sociala praktiker där de tillsammans läste olika former av text i funktionella sammanhang. Vår analys är att läs- och skrivundervisningen även i den här praktiken genomfördes $i$ ett starkt funktionaliserat sammanhang. Läraren gav eleverna möjlighet att meningsskapa om teknikinnehåll utifrån olika texttyper, men lyfte eller tydliggjorde inte på vilket sätt funktion, form och innehåll i olika texttyper hänger ihop. Läraren hade kunnat stödja elevernas läs- och skrivutveckling i högre grad genom att i samband med exempelvis teknikutforskandet utifrån skriven och visuell faktatext berätta för eleverna vad som kännetecknar en faktatext (jfr Langer, 2001; Liberg, 2008).

\section{Praktiker som stödjer kritiskt utforskande}

Vid några tillfällen gavs eleverna möjlighet att meningsskapa i praktiker som vi kategoriserat som kritiskt utforskande. Det kritiska utforskandet framkom dels genom att läraren vid några tillfällen talade om trovärdighet i några av de källor som klassen 
använde, dels genom att läraren ställde frågor som utmanade elevernas erfarenhet av teknik. Ett exempel på när läraren talade om vikten av trovärdiga källor var i samband med att hen presenterade en bok om teknik för eleverna. Läraren beskrev att hen hade tagit reda på att boken var en bra källa som hade trovärdig information: "Boken handlar om teknik, det är ingen bok egentligen utan det är bara papper, ett häfte, då har vi tagit reda på att det här är en bra källa, med riktigt sann information.” Efter att läraren gjort denna presentation betraktas innehållet i boken som "sant" och det var ingen som ifrågasatte bokens innehåll under de kommande lektionerna. Läraren beskrev inte hur hen gjort för att försäkra sig om att innehållet var "sant". Genom att läraren talade om källan som trovärdig uttrycks implicit att det finns texter som inte är trovärdiga. Läraren pekade däremot inte, under våra observationer, på att det också är av betydelse att se på vem som konstruerat texten, hur den är skriven och vad den säger, vilket i högre grad hade kunnat stödja elevernas kritiska förhållningssätt. Läraren problematiserade inte heller hur ordval och uttryckssätt kan användas till att skapa text för ett visst ändamål, eller att texter inte är neutrala utan alltid representerar något perspektiv.

\section{Analys av undervisningens genomförande}

I samband med teknikundervisningen ser vi hur läraren skapade möjligheter för eleverna att tillsammans, i funktionella och meningsfulla sammanhang, kritiskt utforska och förstå den tekniska utvecklingen. När klassen såg på film eller tog del av skriven text, lyfte läraren främst frågor om textens innehåll, men problematiserade inte att texter alltid representerar något perspektiv. Läraren tog inte heller upp hur ordval och uttryckssätt kan ge olika bilder av världen. Vår analys är att den läs- och skrivutvecklande undervisningen även i den här praktiken genomfördes som starkt funktionaliserad undervisning (jfr Langer, 2001; Liberg, 2008).

\section{Diskussion}

Syftet var att utveckla kunskap om läs- och skrivutvecklande sociala praktiker i teknikundervisning i en förskoleklass. Analyserna riktades mot att synliggöra praktiker som elever erbjöds att medverka i för att utveckla läs- och skrivförmåga, det vill säga praktiker som stödjer kodning, textskapande, textanvändning och praktiker som skapar utrymme för kritisk analys (Freebody \& Luke, 1999). Studien är genomförd i liten skala och gör inte anspråk på att vara heltäckande eller generaliserbar, men ger inblick i möjligheter att stödja alla elevers läs- och skrivutveckling i samband med teknikundervisningen i förskoleklass.

Tidigare studier, som är presenterade i introduktionen av denna text, visar att det har betydelse för elevers lärande att läs- och skrivundervisningen sker i ett meningsfullt sammanhang. Vi ser att de teknikutforskande sammanhangen i den här studien skapar rikliga möjligheter att stödja elevers läs- och skrivutveckling genom social interaktion och i meningsfull kontext i de fyra aktuella textpraktikerna, vilket utgör 


\section{T. Alatalo och A.-M. fohansson}

studiens bidrag till forskningsområdet. Nedan diskuteras studiens centrala fråga:Vilken läs- och skrivutvecklande undervisning möjliggörs i teknikundervisningen?

Till skillnad från tidigare forskning, som sett att förskoleklassens läs- och skrivundervisning sker formaliserat och skilt från elevers vardag och erfarenheter (Aminoff, 2017; Fast, 2007; Sandberg, 2012; Skoog, 2012), ser vi att det på tekniklektionerna i den här studien sker läs- och skrivutvecklande undervisning i meningsfulla sammanhang och utifrån elevers individuella förutsättningar. Olikt ovan nämnda forskare har vi studerat läs- och skrivutvecklande praktiker i teknikundervisning, vilket kan ha betydelse för vårt resultat. I praktiker som stödjer kodning framkommer avkodning och skrivande samt reflektion över innebörden av ord. Teknikundervisningen ger också många möjligheter för eleverna till såväl individuellt som gemensamt användande och skapande av olika texttyper. Samtalet rör sig ut ur texten och kopplar till elevernas erfarenheter genom att läraren lyfter frågor och möjliggör för eleverna att reflektera utifrån egna erfarenheter. Sådant textutforskande skapar mening och förståelse om omvärlden (Barton, 2007).

Den läs- och skrivundervisning som synliggörs sker i huvudsak i starkt funktionaliserade sammanhang. Det uppkommer diskussioner om ord och begrepp i meningsfulla kontexter, men läraren undervisar inte explicit om att ord kan ha olika innebörder eller att ord kan sättas samman och bilda nya ord, vilket Nauclér (1989) anser vara gynnsamt för stavningsförmågan. Läraren ger också eleverna möjlighet att skapa, utforska och använda olika texttyper såväl muntligt, visuellt som skriftligt i samband med teknikundervisningen. Vi uppfattar att praktiker som stödjer kritiskt utforskande av text skapas som en naturlig del när teknikfrågor lyfts och förklaras med stöd i visuella, muntliga och skrivna texter, men att läraren inte uppmärksammar eleverna på att texter har ett syfte eller hur det syftet avgör textens form och innehåll. Slutsatsen är att läraren inte inkluderar undervisning om språkets form eller om texttypers kommunikativa delar i samband med teknikutforskandet, utan då är det teknikämnet som ensamt är i fokus. Studien visar på viktiga möjligheter för lärare att stödja elevers läs- och skrivutveckling i samband med olika ämnesområden.

Studiens slutsatser om att teknikutforskande sammanhang kan skapa rikliga möjligheter att stödja elevers läs- och skrivutveckling genom social interaktion i de fyra aktuella textpraktikerna är betydelsefulla med tanke på skolans kompensatoriska uppdrag (Skolverket, 2018). Det är av betydelse för barns läs- och skrivutveckling att få språkstimulans i funktionella sammanhang och i en social interaktion på det vis som vi har visat i den här studien (Gillen \& Hall, 2003). Sådan språkstimulans är betydelsefull för alla elever, men särskilt för elever från utbildningsmässigt mindre gynnade hemförhållanden (Lonigan, 2015), och elever som möter läs- och skrivinlärningen på ett språk som inte är deras (Cummins, 2011).Vi menar att studiens kunskapsbidrag kan ge insikter som är väsentliga för förskollärar- och lärarutbildningen likaväl som för fortbildning av verksamma lärare i förskoleklass samt för speciallärare och specialpedagoger. Eftersom tidigare forskning, och även den här studien, indikerar att lärare i förskoleklass i huvudsak utgår från kognitivt inriktade tankesätt $\mathrm{i}$ 
läs- och skrivundervisningen, blir den här studiens synliggörande av att teknikämnet möjliggör läs- och skrivundervisning i sociala praktiker betydelsefull: när lärare har kunskap om hur de kan skapa språkstimulerande undervisning inom olika ämnesområden, har de förutsättningar att planera läs- och skrivundervisning som integrerar det som ska läras i en helhet och i ett sammanhang där det fyller en funktion, samt undervisa om delarna separat i väl strukturerade undervisningssammanhang, det vill säga i en balanserad läs- och skrivundervisning (Langer, 2001; Liberg, 2008). Sådan undervisning har visat sig främja elevers läs- och skrivlärande (Langer, 2001). Vi menar att lärare behöver medvetandegöras om dessa möjligheter.

\section{Begränsningar och vidare forskning}

Den här studien är avgränsad till att synliggöra läs- och skrivutvecklande undervisning endast i samband med planerade tekniklektioner, vilket kan ses som en begränsning eftersom teknikundervisning kan ha skett även vid andra tillfällen. Vi ser emellertid att analyser av de planerade tekniklektionerna har varit tillräckliga för att behandla den här studiens syfte. Studien visar tydligt hur många möjligheter det finns att arbeta läs- och skrivutvecklande inom teknikämnet, och förmodligen även inom andra natur- och samhällsorienterande ämnesområden. Fler liknande studier behöver genomföras för att stärka slutsatserna i den här studien. Vidare har exempel på texthändelser i resultatet valts ut som typiska för den läs- och skrivutvecklande undervisning som vi observerat i teknikutforskandet. Andra exempel hade kunnat bidra till att nyansera resultatet ytterligare. En annan begränsning är att studien saknar elevernas röster som en väsentlig del i ett sociokulturellt kunskapsperspektiv. Vi menar att de exempel på undervisning som beskrivs ändå kan visa vilka möjligheter till läs- och skrivundervisning i social interaktion som finns i den observerade teknikundervisningen.

\section{Forfatterbiografi}

Tarja Alatalo är docent och lektor i pedagogiskt arbete vid Högskolan Dalarna. Hennes forskningsintresse är läs- och skrivdidaktik i förskoleklass och skolans tidiga år samt språk- och kommunikationsutveckling i förskolan.

Annie-Maj Johansson är lektor i didaktik med inriktning mot naturvetenskap vid Högskolan Dalarna. Hennes forskningsintresse handlar om undervisning och lärande inom förskola, förskoleklass och grundskolans tidigare år med fokus på kommunikation och ämnesspråket i NO och teknik.

\section{Referenser}

Aminoff, C. (2017). Samtals- och skriftspråksorienterade lärarledda aktiviteter i förskoleklass. (Licentiatuppsats.) Linköpings universitet. Institutionen för beteendevetenskap och lärande. DOI: 10.3384/lic.diva-136237 Barton, D. (2007). Literacy. An Introduction to the Ecology of Written Language, (2nd ed.). Malden, MA: Blackwell. 


\section{T. Alatalo och A.-M. Fohansson}

Beck, I. L., \& McKeown, M. G. (2007). Increasing young low-income children's oral vocabulary repertoires through rich and focused instruction. Elementary School fournal, 107, 251-273.

Bergöö, K., \& Jönsson, K. (2012). Glädjen $i$ att förstå: språk- och textarbete med barn. Lund: Studentlitteratur.

Björk, M., \& Liberg, C. (2003). Vägar in i skriftspråket. Stockholm: Natur och Kultur.

Clay, M. (1966). Emergent Reading Behaviour. Auckland University. Psychology, 96, 660-670.

Comber, B. (1997). Literacy, poverty and schooling: working against deficit equations. English in Australia, 119/120, 22-34

Cummins, J. (2011). The intersection of cognitive and sociocultural factors in the development of reading comprehension among immigrant students. Reading and Writing: An Interdisciplinary fournal 25(8), 1973-1990.

Cunningham, A. E., \& Stanovich, K. E. (1997). Early reading acquisition and its relation to reading experience and ability 10 years later. Developmental Psychology, 33, 934-945.

Dickinson, D. K., \& Caswell, L. (2007). Building support for language and early literacy in preschool classroom trough in-service professional development: Effects of the literacy environment enrichment program (LEEP). Early Childhood Research Quarterly, 22(2), 243-260.

Fast, C. (2007). Sju barn lär sig läsa och skriva: familjeliv och populärkultur i möte med förskola och skola (Akademisk avhandling). Uppsala: Acta Universitatis Upsaliensis.

Freebody, P., \& Luke, A. (1999). Further notes on the Four Resources Model. https://pdfs.semanticscholar.org/ a916/0ce3d5e75744de3d0ddacfaf6861fe928b9e.pdf.

GDPR. (2016). The General Data Protection Regulation. Nedladdad 21 april 2019 https://www.datainspektionen. se/lagar--regler/dataskyddsforordningen/.

Gillen, J., \& Hall, N. (2003). The emergence of early childhood literacy. I N. Hall, J. Larson \& J. Marsh (Red.), Handbook of Early Childhood Literacy (s. 1-12). London: Sage.

Hammersley, M., \& Atkinson, P. (2007). Etnography Principles in Practice. New York: Routledge.

Hindman, A. H., Wasik, B. A., \& Erhart, A. C. (2012). Shared book reading and head start preschoolers' vocabulary learning: The role of book-related discussion and curricular connections. Early Education and Development 23(4), 451-474.

Hofslundsengen, H., Eriksen Hagtvet, B., \& Gustafsson, J. (2016). Immediate and delayed effects of invented writing intervention in preschool. Reading and Writing: An Interdisciplinary fournal, 29(7), 1473-1495. http://doi.org/10.1007/s11145-016-9646-8

Lago, L. (2014). "Mellanklass kan man kalla det". Om tid och meningsskapande vid övergången från förskoleklass till årskurs ett (Akademisk avhandling). Linköping: Linköpings universitet, Institutionen för samhälls- och välfärdsstudier.

Langer, J. A. (2001). Beating the odds: Teaching middle and high school students to read and write well. American Educational Research fournal, 38(4), 837-880.

Liberg, C. (2008). Läs- och skrivutveckling och ett utökat läraruppdrag. Hämtad 4 december 2018 från www. ep.liu.se/ecp/032/004/ecp0832004.pdf.

Lonigan, C. J. (2015). Literacy development. I R. M. Lerner, L. S. Liben, \& U. Mueller (Red.), Handbook of child psychology and developmental science, cognitive processes, (Vol. 2, s. 763-805). Hoboken, NJ: John Wiley \& Sons.

Luke, A. (2000). Critical literacy in Australia: A matter of context and standpoint. Fournal of Adolescent $\mathcal{E}$ Adult Literacy 43(5), 448-461.

Lundberg, I., Larsman, P., \& Strid, A. (2012). Development of phonological awareness during the preschool year: The influence of gender and socio-economic status. Reading and Writing: An Interdisciplinary fournal, 25(2), 305-320.

Nauclér, K. (1989). Hur utvecklas stavningsförmågan under skoltiden? I C. Sandqvist \& U. Teleman (Red.). Språkutveckling under skoltiden. Lund: Studentlitteratur.

Palincsar, A. S., \& Brown, A. L. (1984). Reciprocal teaching of comprehension-fostering and comprehensionmonitoring activities. Nedladdad 4 november 2018 http://people.ucsc.edu/ gwells/Files/Courses_Folder/ ED\%20261\%20Papers/Palincsar\%20Reciprocal\%20Teaching.pdf

Patton, M. Q. (1990). Qualitative Evaluation and Research Methods. Newbury Park: Sage Publications.

Pearson, P. D., Hiebert, E. H., \& Kamil, M. L. (2007). Vocabulary assessment: What we know and what we need to learn. Reading Research Quarterly, 42(2), 282-296.

Sandberg, G. (2012). På väg in i skolan. Om villkor för olika barns delaktighet och skriftspråkslärande. (Akademisk avhandling). Uppsala: Acta Universitatis Upsaliensis.

Schatschneider, C., Fletcher, J., Francis, D. J., Carlson, C. D., \& Foorman, B. R. (2004). Kindergarten prediction of reading skills: A longitudinal comparative analysis. Fournal of Educational Psychology, 96(2), $265-282$. 
Schmidt, C. (2016). Läsa, skriva och förstå texter. Lund: Studentlitteratur.

Skolverket. (2012). Greppa språket. Ämnesdidaktiska perspektiv på flerspråkighet. Stockholm: Fritzes.

Skolverket. (2018). Läroplan för grundskolan, förskoleklassen och fritidshemmet. Stockholm: Skolverket.

Skoog, M. (2012). Skriftspråkande i förskoleklass och årskurs 1. (Akademisk avhandling). Örebro: Örebro Studies in Education.

Vetenskapsrådet. (2017). God forskningssed. Stockholm: Vetenskapsrådet.

Wiksten Folkeryd, J., af Geijerstam, A., \& Edling, A. (2006). Textrörlighet - hur elever talar om egna och andras texter. I L. Bjar (Red.). Det hänger på språket! Lärande och språkutveckling I grundskolan, s. 169-188. Lund: Studentlitteratur.

Wright, T. \& Neuman, S. (2013). Vocabulary instruction in commonly-used kindergarten core reading curricula. fournal of Literacy Research, 46, 330-357.

Wright, T. \& Neuman, S. (2015). The power of content-rich vocabulary instruction Perspectives on Language and Literacy, (41)3, 25-2

Yin, R. K. (2015). Fallstudier, design och genomförande. Stockholm: Liber. 